\title{
Tekná - a vanishing oral tradition among the Kayan people of Sarawak, Malaysian Borneo
}

\author{
Roselind Wan, Sumathi Renganathan and Inge Kral
}

\section{ABSTRACT}

The documentation of the oral traditions of non-literate indigenous communities is a vital aspect of the preservation and survival of indigenous knowledge, culture and tradition. In this article, we discuss tekná, an oral tradition of the Kayan people in Sarawak. Here we trace not only the historical background of tekná, but also explore its current status and practices among the Kayan. We present an example of tekná sung by a Kayan elder. This forms the basis for a discussion about how the tekná is performed, sung, and narrated, as well as the possible meanings and interpretations that can be gleaned from this tekná. Finally, we suggest approaches to documenting oral traditions like the tekná that show promise for the preservation of this fragile oral tradition for future generations of Kayan.

KEYWORDS

Indigenous; Kayan; oral history; oral tradition; Sarawak; song; tekná

Ee e marung tatah Ubong dih belingah deh menaring - jewey

Ket nun hadui daha na te alem uma dih menuna - jewey

Tiah kenep daha puyo nilung ngakap te ida liling - ateh

Like the story of Ubong in the beginning,

What did they do in the old days?

They were of one heart my child.

(Tekná sung by Aren Jok, December 2014)

\section{Introduction}

Oral traditions for non-literate indigenous people serve as repositories of their history and cultural

heritage. Hence, the preservation of these oral traditions becomes crucial for the survival of 
indigenous languages, culture and history. However, more often than not, traditional forms of oral expression are not documented leading to the knowledge, language and culture embedded in these oral traditions to be lost forever. In addition, when indigenous communities shift to using a dominant language, it can have devastating effects not only for the minority indigenous language, but also for translating the archaic terms embedded in these oral texts (Turin 2013). Thus, recording and documenting these oral traditions with the last practitioners of these verbal arts is a vital step in the preservation and survival of the culture and traditions of non-literate communities, especially the intangible heritage expressed through their language. In countries such as Australia (Marett and Barwick 2003; Thieberger 2013; Turpin 2011), the United States (Field and Cuero 2012; Parks et al. 1999) and Canada (CBC-Aboriginal 2010; Cherubini 2008; Jensen 2015), there have been efforts to document and preserve the oral traditions of their respective indigenous communities. By contrast, there have been fewer efforts for indigenous communities in countries like Malaysia (Nicholas 2004) and we will address this gap by focusing on tekná, an oral tradition of the Kayan people in Sarawak.

This article begins with an overview of the Kayan people and their migration history based on their oral history. Following this we refer to the tekná of the Kayan of Long Panai, Sarawak. ${ }^{1}$ We explore the historical background and the present-day situation of tekná, and present one tekná sung by Kayan elders and discuss the written text. We then focus on an excerpt of this tekná sung by elders in Long Panai. We also discuss the changes and concerns regarding this oral tradition and the local realities expressed by many members of the Kayan community as they observe this

\footnotetext{
${ }^{1}$ Long Panai is a Kayan longhouse by the Tutoh tributary of the Baram river. The Kayan here are known as the Uma Beluvuh Kayan and they speak the Uma Beluvuh variety of the Kayan language.
} 
tradition on the verge of disappearing. We conclude by arguing that strategies need to be implemented to maintain the relevance of such oral traditions for future generations.

\section{The Kayan: historical background and migration to Sarawak}

The Kayan are indigenous to the island of Borneo. While the majority of the Kayan population is found in Kalimantan on Indonesian Borneo, a smaller population (approximately 27,000) live in Sarawak on the northeastern Malaysian side of Borneo. The Kayan language includes Kayan Uma Pu, Kayan Uma Bawang, and Kayan Uma Peliau varieties. The Kayan spoken by the inhabitants of Long Panai is known as 'Uma Beluvuh', and it is peculiar to the Kayan in this longhouse. The Kayan, being a non-literate people, have no written history and hence suggestions made regarding the origins of the Kayan are mostly based on their oral narratives. There is in fact an old claim made by Charles Hose (Hose and McDougall 1912) that the Kayan might have originated from the basin of the Irrawaddy in Burma through the Malay Peninsula and Sumatra in the early 14th century, but this has not been followed through by scholars. Therefore, to a large extent, Kayan knowledge of their origins remains tied to postulations transmitted orally over the generations through storytelling and the tekná.

Based on anthropological accounts regarding the origin of the Kayan of Sarawak, scholars have suggested that the Kayan migrated from their ancestral homes in the Apo Kayan in Kalimantan, Indonesia, to Sarawak sometime in the early 18th century (Anyie 1995; Rousseau 1990). However, little is known about why they migrated and from conversations between Wan (Author 1) and Kayan elders in Long Panai, they have nebulous knowledge of their migration history. What we

know from their oral history is that the migrations and movements of the Kayan were attributed to 
many factors. These may have included their need to cultivate new land for farming and their pagan beliefs and practices, whereby bad omens may also have necessitated a move away from their old place. In some cases, the migration could have been as a result of disputes between longhouses or tribes. During periods of the early 18th century, for instance, warfare among tribal groups was rife and attestations from their oral history reveal the Kayan lived in constant fear of war.

A popular tale illustrates the migration of the Kayan. This oral history, told by Kayan elder Taman Harun in $2014,{ }^{2}$ describes the unfortunate incident that is said to have caused the eventual split between the Kayan population that stayed in Kalimantan, Indonesia, and those Kayan who crossed over to Sarawak. Back in those early days, as the story goes, it was normal for the Kayan to hunt for wild boar and deer. During the aftermath of one such hunting expedition, a commotion occurred in the longhouse, as Taman Harun recounts:

There was loud screaming and chaos in the longhouse. You see, in the old days there were constant wars amongst the different tribal people. The Kayan people were living in constant fear and uncertainties. Rumours of tribal warfare were rife. It was said that one day people were aroused from their sleep by a loud noise. Shouts were heard. They couldn't discern exactly what was said, but what they thought they heard was the word ayau which means bandits or enemies, [popularly referred to as 'headhunters']. Under such circumstances when people were always

\footnotetext{
${ }^{2}$ Taman Harun is in his eighties and lives in Long Panai. He still practises shifting cultivation for hill paddy, an old farming tradition which like many other old practices of the Kayan is no longer part of contemporary life. As a young man he learned the payau story from his elders as well as through listening to the tekná. He himself does not know how to sing tekná although like most Kayan in his generation, he can echo the tekná.
} 
fearful of war and headhunting, the word ayau caused panic among the people. Nearby was a big river and an old bridge for crossing the river. The Kayan, in their haste and fear of what they believed were headhunters about to attack, fought their way towards the bridge to cross to the other side of the river. Alas, due to the heavy weight of the people on the bridge, it collapsed. Those Kayan who managed to cross over became the Kayan who now live in Sarawak. While those left behind, and there were many of them, became the Kayan of Kalimantan. That is the story of how the Kayan migrated. This explains how the Kayan people became the Kayan of Sarawak, and those left in Kalimantan become the Kayan of Kalimantan. As the story goes, it was later established that the word that they had misheard was in fact payau [deer] and not ayau.

(Taman Harun, field interview, 2014)

MacDonald (1956: 16) suggests, perhaps misleadingly, that the people of Borneo considered headhunting their favourite sport. It is clear, however, from most Kayans’ accounts of headhunting, and what can be surmised from Taman Harun's story, that headhunting was neither a sport nor was it something that they would relish as an entertaining pastime. Having no written history, this oral story of the incident that led to the split between the two groups as a result of the confusion between the word ayau and payau remains a popular account of Kayan migration to Sarawak. 


\section{Oral traditions of the Kayan}

For the Kayan-community in Sarawak, their oral traditions include forms such as the lung, leken, lakuh $h^{3}$ as well as the tekná, and these provide a rich insight into Kayan history and culture. The latter, tekná, is a chanting song (Southwell 1980) or 'song-tale' (Morgan 1980). ${ }^{4}$ It may be considered comparable to the song cycles of the Kumeyaay indigenous people of Baja, California (Field and Cuero 2012) in that, like their 'bird songs', the tekná also evokes the cultural values, worldview and philosophical orientations of the Kayan. With no written history, tekná songs form a valuable repository of Kayan history and culture. Kayan singers (who could chant, sing and narrate stories) disseminated this knowledge and were considered artisans, and held in high esteem by the community. Over recent decades however, pressures from the outside world have forced the Kayan to undergo many social and cultural changes that have had dire consequences for the survival of their traditional oral culture. The mass conversion of the Kayan to Christianity in late 1940 following the Christian revival among the Kelabit people in Bario Highland (Janowski 1991) was a major factor that led to the initial loss of the tekná among the Kayan. W. Anyi, a Kayan elder from Long Panai recalls how at the height of the Christian (Bario) ${ }^{5}$ revival in 1970s, Christian evangelists impressed on the Kayan that they should change their old traditional practices which were deemed 'un-Christian'. This was the turning point that has had far reaching effects on the traditional way of life for the Kayan. Converting to Christianity meant leaving behind the old ways and behaviour associated with paganism. Additionally, the singing of the tekná was associated

\footnotetext{
${ }^{3}$ These include stories of heroic mythic figures such as Lung Lake' Lakin, or of ghosts such as Lung To', as well as funny stories of blunders and silliness such as Lung Lebui dawa Duyu. To the first author's knowledge, these oral tales have not been written down.

${ }^{4}$ The Kayan tekná is perhaps also similar to the sung tales from the Papua New Guinea highlands, see Rumsey and Niles (2011).

${ }^{5}$ The Christian revival which started in Bario Highlands amongst the Kelabit has had a far reaching impact on the traditional practices of indigenous peoples in Sarawak. It was said to have begun with schoolchildren from a secondary school in Bario in 1973 (Janowski 1991). This Christian influence extended to the Kayan areas in the Baram district. Consequently, from elders' accounts, almost all the Kayan in the Baram embraced Christianity.
} 
with drinking burak, a popular rice wine among the indigenous peoples of Sarawak, including the Kayan. Young men were reproached for getting drunk as consequence of their drinking the burak and this was not a practice looked kindly upon by the new Christians. Even more damaging for the tekná was that people who sang it were accused of singing to 'call to the devil' because the narration of the tekná relied on old forms of lyrical expression involving supernatural spirits and animistic forms:

I remember in the evening when some of us sang the tekná, people would ridicule us as drunkards: 'Oh, look at them they say, they are going to call on the devil ... .' This was a very unfortunate thing to have happened because it demeaned us. And during the Sunday sermons, the pastor would advise us that instead of singing the tekná, we should sing gospel hymns. Since then, many of those who can sing tekná stopped singing because it was considered satanic.

(W. Anyi, interview October 2015)

Such negative connotations associated with the tekná resulted in a reduced interest to learn and sing the tekná. Further, the mass conversions of the Kayan had created a need within the Christian church to have Kayan pastors. Therefore, young men and women were encouraged to attend mission schools and many Kayan in later years became pastors serving the Sidang Injil Borneo. ${ }^{6}$ Consequently, there was a substantial period where many of the traditional and cultural practices of the Kayan were marginalised. According to W. Anyi, interest in the tekná was only rekindled

\footnotetext{
${ }^{6}$ Sidang Injil Borneo, an offshoot of the Borneo Evangelical Mission (BEM) instituted by the Australian missionaries (Southwell 1999) is the largest indigenous church in East Malaysia in terms of membership. SIB churches are now known officially as BEM. Reverend Dato’ Dr Justin Wan, who is a Kayan from Long Panai, is the current President of BEM, Sarawak.
} 
after an influential Kayan pastor, Reverend Dr Justin, sang a modern interpretation of the tekná with lyrics based on biblical stories which was performed at an $\mathrm{irau}^{7}$ in 2002.

Around the same time, other significant changes were experienced by the Kayan, particularly with the introduction of schools for the Kayan. Traditionally, the Kayan are farmers, and rely on subsistence farming as their main means of survival. With most younger Kayan getting an education, this opened the way for them to gain salaried employment in the towns. As a result, rural-urban migration in the early 1970s further fractured the importance of tekná among the Kayan. Educated Kayan began to move their families to towns, and the younger generation unfortunately suffered the loss of traditional practices that were very much part of a Kayan upbringing in the past.

The impact of Christian influence and other structural changes to the Kayan way of life (such as the opening of mud road for logging which provides crucial access to the nearest town, Marudi, and better education for Kayan children) are equally significant. The Kayan, like other indigenous groups in Sarawak, are shifting from the old traditions to embracing modernity, thus the important role played by tekná in transmitting Kayan culture has been lost in the process. The Kayan now mostly live in the town, and performance of the tekná has been relegated to being merely a stylised cultural performance at social events. While these changes are inevitable, they have become more apparent over the last few decades. Additionally, as more and more Kayan people have chosen to live away from their traditional dwelling in the longhouse, many of their traditional practices have

\footnotetext{
${ }^{7}$ The irau is an annual religious festival held by Kayan indigenous churches. The next irau is expected to be held in June 2018 in Long Panai.
} 
declined in their functions. ${ }^{8}$ In other words, the oral practices that were synonymous with a communal way of life in the longhouse are no longer seen by the younger generation as having much importance, nor do they contain the same relevance in their new social environment. For some Kayan, especially the younger generation, these oral traditions are unabashedly considered remnants of an old culture that has no role in modernity.

Surprisingly, unlike other indigenous communities in Sarawak such as the Iban and the Penan, ${ }^{9}$ the oral traditions of the Kayan have not received adequate attention in scholarly literature. Although there have been anthropological studies on the Kayan of Sarawak (Hose and McDougall 1912; Rousseau 1975, 1983, 1990, 1998), minimal attention has been paid to documenting or describing the tekná. One exception is Jau et al. (2011), whose exploratory project on Baram tekná offers a preliminary attempt at describing the vocal aspects of tekná. Baram tekná generally refers to the tekná sung by the Kayan people of the Baram region, a sparsely populated district located in northeast of Sarawak (see Figure 1).

\footnotetext{
${ }^{8}$ The indigenous peoples of Sarawak generally live in longhouses which is a row of household units under one roof (see Kelbling 1983). A Kayan longhouse consists of several units commonly referred to as the amin, with each unit having a door opening out onto a long hall of about twenty or more feet in width, which runs the full length of the house. A longhouse can sometimes consist of 50 or more amin, although there are some longhouses such as the Long Panai longhouse that has more than 100 amin.

${ }^{9}$ The Iban is the largest group of indigenous peoples in Sarawak, while the Penan is one of the smallest. Studies on the two groups are popular amongst scholars and the literature on their oral traditions is well developed. For a discussion on the sung poetry of the Sarawak Dayaks, see Rubenstein (1985).
} 


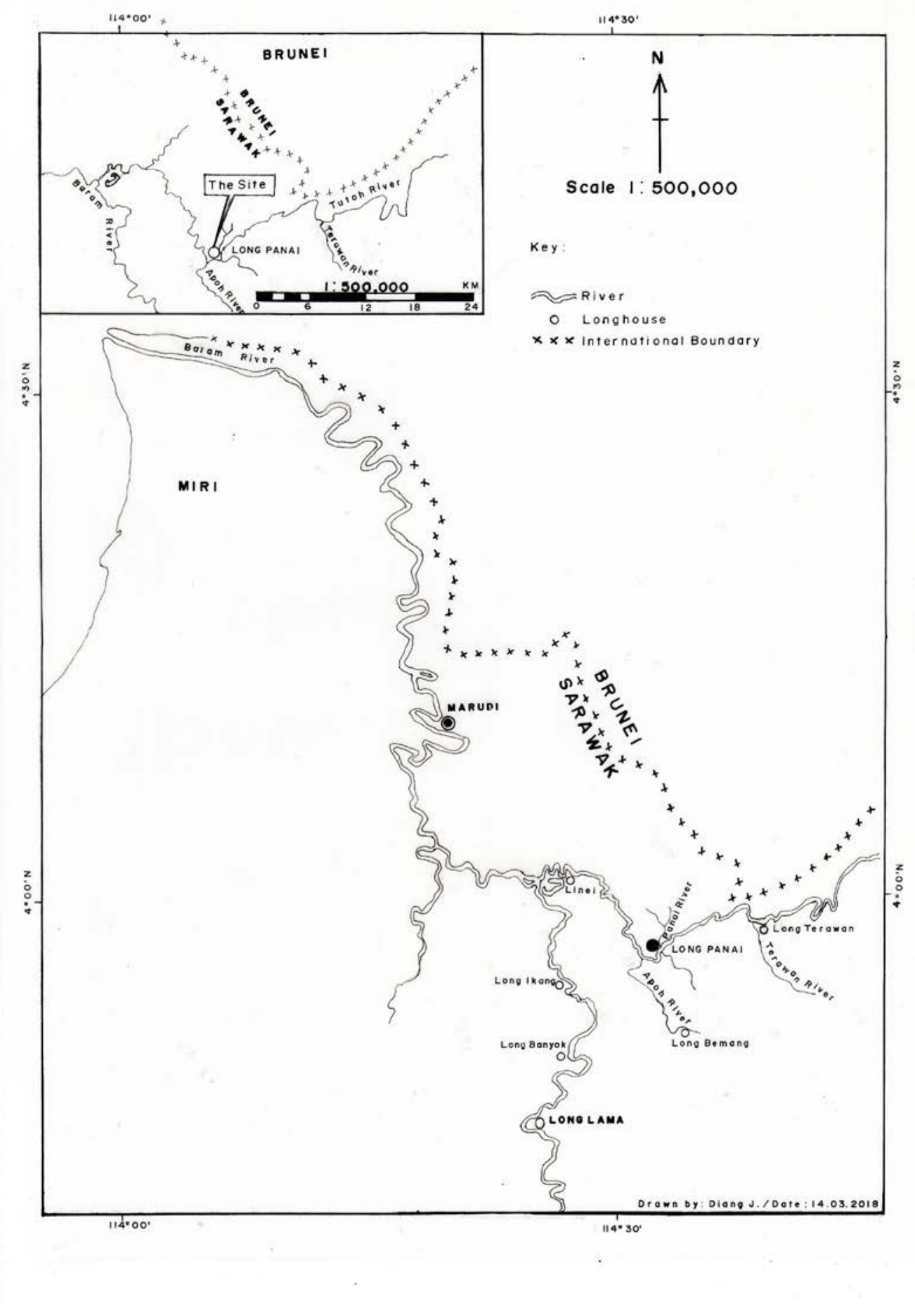

Figure 1 Long Panai longhouse by the Tutoh river in Sarawak, Borneo, East Malaysia. Drawn by Diang Jok, 5 March 2018.

Figure 1 Long Panai, Baram district, Sarawak. Map by Diang Jok, from Long Panai. 
As in many indigenous cultures globally, oral traditions like the tekná, are endangered. The fear of this potential loss is keenly felt by the first author (Roselind Wan), a Kayan woman in her early fifties who, like many in her generation, lacks the required skills and knowledge to sing or even echo the tekná. ${ }^{10}$ During fieldwork, it became apparent that there are only four singers in Long Panai who can sing the tekná. Apart from Aren Jok, the singer of the tekná discussed later, the other three are Lake' Imu, an elderly man in his late eighties, and two older women, Lahung Anyie and Paya Ding who are in their early seventies. In the past, most of the older generation were singers of the tekná but many of those who could sing have died or are too old to sing. Whilst cowriting this article, a gifted tekná singer who was also Aren Jok’s father died recently of old age. For Kayan oral culture, his passing and those of his generation always seem to herald a deep sense of loss.

There is no doubt that the tekná tradition is appreciated by the younger generation, but from our observation it is apparent that there is little interest to learn this art. Perhaps, as most are brought up in the town, they are not exposed to the tradition, except during their return to the longhouse. Conversations with some young women offer insights on how the tekná is perceived by the younger generation, and illustrate how although they acknowledged tekná as symbolic to their Kayan identity and culture, they see it more as a form of 'archaic' entertainment. One young girl described the tekná as 'songs of our grandmother', hinting at its reference to the past and not the

\footnotetext{
${ }^{10}$ Having strong familial ties to the community, Author 1 (Wan) frequently visits her longhouse at Long Panai. It was during those visits that she noticed the unfortunate decline in many of the oral traditions of the Kayan. She felt privileged to have been able to talk to the remaining few tekná singers of Long Panai, and her desire to document some aspects of their diminishing tradition motivated the writing of this article.
} 
future, 'I listened to the tekná when it was performed during Christmas. But then I did not understand the song. They used the old language. In fact, even my mum didn’t fully comprehend the lyrics although she seems to enjoy it. Tekná is such an old thing [ket menuna]; only my grandmother will be able to sing it.' Generally, elders think the tekná is too complicated to be taught. Indeed, in a separate interview with elder Lake' Imu, he was bemused when asked if he taught the tekná to his children. Tekná according to him, is not something that can be taught easily; but if one has the passion, it can be acquired through observation:

Awi ngenep, en mengale, avin nutih ket atih. En ta pengale, te kah uge ta uk, en sabungsabung nah, en tabah nah, ju nah lahoh ... nutih nah kereh. Bi kelalo tusah. Tusah. Avin iha pahavin, pahavin. Atih aleng ta em nuno sayu jam na.

If one has the passion, it can be learned through observation and practice. But it is a difficult art, and one must have enough experience to know how to come up with spontaneous lyrics and be skilful to sing it.

He believes that it is a talent that is inherited, or gifted, from God, and although young people could learn, it requires experience and wisdom to extempore the lyrics befitting each tekná.

Initial observations in the longhouse revealed that many Kayan are unaware of the impact that the potential loss of the tekná may have to their culture. In embracing modernity, the Kayan have perhaps become oblivious to the significance of some of these oral traditions. The loss of tekná equates with the loss of cultural memory and historical references that are embedded in this oral tradition. Since the younger generation Kayan do not grow up in a longhouse they are therefore 
not socialised into the culture and the language. Consequently, later generations may feel distanced from their own history, heritage and origins and which may only be reclaimed through cultural or even linguistic revitalisation. Perhaps like poetry and poets, interest needs to be cultivated from within, and the expression of which requires passion in order for the learning to happen. Sadly, at the point of writing, except for one young man $^{11}$ from the Belaga district ${ }^{12}$ who is still learning the art from his grandmother, transmission of this tradition is no longer taking place.

\section{Tekná: chanting, singing and storytelling}

According to Jau et al. (2011) tekná can be divided into two categories. The first is the tekná asen (the original old tekná) that is part of the oral traditions of the Kayan of centuries past, and it depicts Kayan legends and tales of the supernatural world. One example of the tekná asen is the epic story of Belawan in tekná Belawan. This type of tekná is inherited with the skills and knowledge of the tales passed down to the singers from their ancestors. Although most of the tales sung are memorised legends and folktales, some of the narrations could also have been acquired through dreams as in the tekná asen sung in tekná Laleng. ${ }^{13}$ The tekná asen in its original form is considered by older Kayan to be the best form of this oral tradition.

\footnotetext{
${ }^{11}$ Adrian Jo Milang, aged 19, delivered an interpretation of the tekná maring in March 2017 (Pakar 2017). However, unlike in the past when tekná were impromptu, his tekná which he titled 'Tiger's son comes to the land of cats' was composed and rehearsed prior to his performance in a hotel in Kuching, Sarawak.

${ }^{12}$ The Belaga district is located in the Kapit division, near Bintulu. The majority of the Kayan population is found in the Baram district where this study was conducted.

${ }^{13}$ Laleng Paya Wan was a well known tekná singer. Her tekná is known among the Kayan as 'tekná Laleng' (Jau et al. 2011: 201).
} 
The second category is the tekná maring (or new tekná) which is the modern version of the tekná. Unlike the tekná asen that encompasses tales of the supernatural world and narration drawing on dreams and arcane references, the tekná maring embraces the new social context of the Kayan who after the late 1940s became Christians. Mostly now, the narration and lyrics are sung in response to the context, event or reason why the singer is called upon to sing the tekná. For example, new narratives of the tekná maring may include biblical stories, praise, advice, and refer to relationships past and present.

The category of tekná and occasions for which the tekná is being performed determines the content of the tekná. In times past, the singing of the tekná was more frequent and occasion for singing it could be the gathering of longhouse folks who, tired after a long day of hard work on the farm, came together to sing the tekná. In this context, the tekná was a form of entertainment, to sing the night away, or a way for young men and women to spend their leisure time together. Meanwhile on other occasions, usually with the tekná maring, it could also be a mode for welcoming guests to the longhouse. Visitors to Kayan longhouses in the past were rare and few, thus they were welcomed not only as honoured guests of the headman, but of the whole longhouse. In cases where the visitors were government officers, the headman or his representative through the narration of the tekná, would subtly relay their hopes and wishes for the people in the lyrics of the tekná. It appears that the tekná maring was then more of a mode of entertainment rather than story-telling. However, when modern forms of entertainment became available to them in the longhouse (such as the radio, television or from the Internet), the tekná maring was increasingly seen as a cultural performance reminiscent of the past. Nonetheless, the tradition of tekná continues to define what it means to be Kayan and is emblematic of past traditions. More recent forms of the tekná maring 
generally include biblical stories, as well as advice and moral interpretations when performed in religious gatherings.

In their exploratory study of the Baram tekná, Jau et al. (2011: 6) list the different subtypes of the tekná.: tekná Labang, tekná Belawan, tekná Usung, tekná Ledang, tekná Jenaro, tekná E-kedi, tekná Lung Lingei, tekná Nurang Dale’ and tekná Jun Tun. Whether these belong to the tekná asen or tekná maring category is not made clear. We will continue to follow Jau et al’s (2011) categorisation in this article. All these subtypes have their own distinctive stories and tune. Tekná Belawan is listed under the tekná asen and is the most famous tekná of all the subtypes. According to accounts from the elders, the tekná asen contains the longest epic story amongst all the tekná. This differs from the tekná maring, in that the tekná asen was usually based on an existing tale, but the tekná maring is typically an impromptu narration in response to a current event. The version of the tekná discussed in here is the tekná Labang which is a subtype of the tekná maring. In most tekná maring other than those which recount biblical stories, lyrics are created in accordance with the purpose for which the tekná is performed.

\section{Performing the tekná}

The tekná is not sung individually, but performed by a group of five or more people. The group is led by a tukang tekná or master singer who narrates the story accompanied by the others who are known as tukang nyabei or echo singers. The tukang tekná is an individual with the gift of nekna (chanting the song) and is regarded by the community as the most skilled in singing the tekná and someone who has acquired a reputation as a master of the art. Although anyone can sing the tekná if they have mastered the art of performing it, in the old days especially for chanting prayer songs 
and dreams, the tukang tekná was usually a shaman. ${ }^{14}$ The tukang nyabei however, refers to a group of chorus singers who echo (nyabei) the last word sung by the tukang tekná. Not everyone has the skills to echo the tekná, and like the tekná singer, the tukang nyabei are those who have learned the art of nyabei through experience and practice. In performing a tekná asen such as that of the tekná Belawan and other old tekná forms, the tukang tekná sings a version of the text that has been memorised. Improvisation may be needed, depending on the expertise of the master singer, but the original story line is retained as it was chanted by the ancestors many centuries ago.

The singing of the tekná is usually done sitting, with the master singer in the middle and the echo singers on both sides. In an informal performance, the audience sits in front or around them. In recent times though, when the tekná is performed during religious services or as a performance on stage, the tekná is sung standing, facing the seated audience. The master singer stands in the middle with the echo singers standing on both sides, close enough to each other so as to allow for a harmonious rendition of the melody. While there is no instrumental musical accompaniment, the master singer sings a line using a melody perfected from practice. ${ }^{15}$ Then towards the end of the line the echo singers join in with an echo word from the line, however this echo word does not necessarily have to rhyme with the final word in that line. ${ }^{16}$ Echo singers when asked how they come up with an appropriate echo word for each line generally refer to their collective memory of what sounds right. ${ }^{17}$ A good tekná is when the echo singers' words are linked appropriately to the

\footnotetext{
${ }^{14}$ Under the old Kayan religion, bungan, the shaman was someone who was a skilled healer.

${ }^{15}$ We do not attempt to analyse the musical component rather we use the descriptive terminology provided by the Kayan informants.

${ }^{16}$ Rubenstein (1989) describes these as 'sound words'. Song language she notes, is generally different from that of ordinary, everyday speech. As illustrated in the Kayan tekná, the sound words used to rhyme with the last word of a sentence are just that, i.e. they carry no meaning but rather are used to accentuate the rhythm and emphasis.

${ }^{17}$ Such 'appropriate' words according to them are generally so-called 'sound' words that they remember from their past. Those words are either coined or borrowed from archaic constructions, e.g. teleh, jewey etc., do not have any meaning except that they are appropriate to use for some end words in the line.
} 
last word in each line and those who understand this art are considered good tukang nyabei. In this way, every line sung by the master singer will be echoed with a similar word, or a new word deemed a suitable reference to the preceding word. ${ }^{18}$ In this form of sung poetry, unlike with a written poem, the lyrics are unscripted and impromptu, composed to fit the occasion and purpose of the tekná at that moment.

Altogether, the poignant tunes chanted melodiously by the tukang tekná and rhythmically echoed by the tukang nyabei are beautifully haunting and evocative of the past, leaving the audience spellbound by their poignancy. Laments for the old ways of the Kayan are invariably included in tekná maring. This is apparent in the tekná of Aren Jok whose narratives are nostalgic reflections on the disappearing way of life of the Kayan, evident in the various references to an idealised past life - (urip) menuna - and the sanctity of 'unity', of being 'one heart'. Aren Jok’s tekná celebrates the past as an ideal existence, where her verses serve to remind us of the good nature of the Kayan. Those are memories that she wants her listeners to retain. Perhaps, tacitly admonishing us for forgetting, but for the Kayan audience, it is in the moment of listening to a tekná that one reminisces about this past and reflects on what it means to be Kayan. Such idealisations are evident in the following translated tekna' song from Aren Jok:

Our people in the old days;

they were (of) one heart, (like) laying down the mat to dry our paddy, their hearts were always together.

\footnotetext{
${ }^{18}$ Some of the echo words are repetitive, following a trace memory of which word should be paired with the last word in the line, which suggests the use of what Fox (2011: 201) refers to as 'formulaic' expressions.
} 
Oh! how wonderful it was then, such was their fortitude.

No matter how hard and difficult

life was,

No matter how we didn't have any education;

Life was good.

But forgive me my dear,

I do not know how to advise you.

Only,

this is the little I know;

choose wisely and persevere, always, until you reach the end.

This is what I know.

\section{Tekná Urip Menuna (Our old lives) sung by tukang tekná, Aren Jok}

The tekná we present here is an example of a tekná maring, as singers in Long Panai are no longer able to sing the tekná asen. Recorded in December 2014 and sung by Aren Jok (see Figure 2), it illustrates the creativity and ingenuity of the rich oral culture of the Kayan. As mentioned earlier, in this longhouse there are currently only four known master singers of the tekná. There is, however, no lack of echo singers, since singing the echo part of the tekná can still be performed by most of the older generation, that is, those in their late fifties or sixties.

Figure 2 Aren Jok, tukang tekná. Photo: Bon Hul, 2016

The tekná described and discussed in the following section is a tekná Labang from the tekná maring category. Aren Jok who is in her early seventies, is known for her ability to sing the tekná and is one of the three active women singers acknowledged for skillful chanting of the tekná maring. She learned how to sing the melody and the haunting tune of the tekná through observation and imitation of the elders who performed during her youth. She has heard of the tekná Belawan, 
but has not heard it chanted. She believes that most Kayan of her generation would not have heard the archaic tekná Belawan. As far as she can recall, no one in the longhouse knows how to chant the tekná Belawan, as she describes:

The tekná Belawan is really the old version of the tekná. I heard about it growing up, but because I did not hear it, I do not know how to sing it. I only learned the tekná maring; the melody, the tune and how to be creative with the lyrics to suit the context of the tekná. My interest in singing came naturally. There was no formal training in how to sing and make up the verses. I only learned through keen observation and practice. The ideas just come to me as I sing it, and they must relate to the context, to the person who is being celebrated or honored, the audience, and the purpose or event for which it is performed. Context of situation determines the content. Creativity of content depends on the expertise of the singer. Collectively, the singer and the echo sounds from the echo singers make a haunting melody for a good tekná performance.

(Aren Jok, field interview, 2014)

True to Aren Jok's claims, the lyrics of the tekná maring that she sang for the first author (Wan) that day were composed on the spot. The impromptu lyrics contained advice relevant to the first author's context, as well as references to the reality of present-day life for the Kayan. Similarly, when Aren Jok performs for functions such as weddings, she formulates in her mind appropriate advice for the couple and their family. Four women volunteered to echo her tekná and they are all women from the same longhouse: Aren Wan is in her early sixties, Puyang Ajeng is 60 and Urei 
Anyi is 54. Another echo singer was the first author's late aunt, Mok Ya (Paya Wan) who was in her early eighties at the time. All the singers live in the longhouse except for Aren Wan who lives in the city. All of them claim that they learned how to echo the tekná through listening to others nekna ('chant', i.e. the verb form of tekná) when they were young women.

The transcription and translation of this tekná was provided by the first author with the assistance of Margaret Lahung Wan. ${ }^{19}$ To the best of our knowledge and ability, the translation here represents the richness of meanings in the tekná, although an accurate representation of the nuanced expressions could not be achieved due to some obscure references made at certain points during the singing of the tekná. The language used in the tekná is a little different from everyday speech, although some vocabulary items are similar, phrases and word substitutions from old Kayan are also used and these are difficult to translate. An example of this can be seen in Aren Jok’s tekná, where she uses the phrase bulan ngembang (full moon), a metaphoric phrase from the Malay language. Although we present a transcribed version of the original tekná sung by Aren Jok, this transcription, as Portelli (2003) cautions, should not and cannot replace the actual oral narrative. This transcribed text is necessarily devoid of its rhythm and melody, thus highlighting the difficulty of capturing the nuanced oral richness. We also acknowledge the fact that meanings embedded in these oral narratives are best perceived by listening rather than by reading (Portelli 2003).

\footnotetext{
${ }^{19}$ Margaret Lahung Wan, a 68-year old elder from Long Panai, is a peer of the singers. However, unlike the singers and most others of their generation, she went to school and became a nursing assistant. She later pursued a Diploma in Nursing when she was in her late fifties and retired as a staff nurse.
} 
In the version below only the underlined words were able to be translated. While this represents the majority of the words, some meaning may have been lost. We return to this issue below. Importantly, the words at the end of each line (- teleh, - liwey, - dan peh, etc.) are the echo sound words and carry no meaning. The Kayan language used in this tekná is of the Uma Beluvuh Kayan variety.

\section{Urip Menuna}

Ee labang hulung men Tinggang-teleh

Ee nah nih di nah kalo, idang dih benliko bulan ngembang - liwey

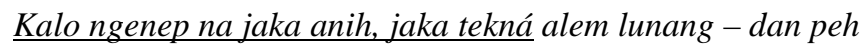

En dalo nahui pah anih muvui nyihu akui - anih

Ee di nah daho' aleng depekenlo dih menuna - jewey

Ee e e nah puyo' ali kui puyo'- teley

Ee nah ika nyihu petira urip men'a dih menuna - jewey

Ha nah ita bara puyo musang tira musang ten ten - liwey

Ee urip daha aleng dih dekaya dih menuna - jewey

Ee dih nah kenep piah daha awi benrat deh menkah - parei

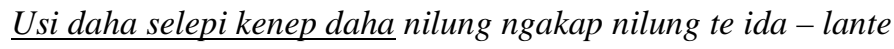

Ee nah dih nunan puyo deh tengaran kui deh uk iduk-edey

Ee nah urip daha lusan taman nih menuna - jewey

Ee nusi main maju dih kelalo sayu dih menaring - jewey

Men dih benlingah avin daha dih na kenep tiah

$$
\text { atih marung aleng - nureh }
$$

Ee nah iha nah daha maju kelalo sayu deh menaring - jewey

Ee menaring uma Long Panai tula uma te Long - Panai

Ee nah ee nah ee nah ngedo anih do hanit - neteh

Avan telo deh men'e anih liveng masi puyo' ali - teteh

Ee marung tatah urip menuna atih kelo taha bulan ngembang - levei
Oh ye the hornbill bird, Tinggang,

Here we are, idang benliko, in a full moon, We wish now, this the time to make tekná.

They called me, sought me out,

They seek words, stories of the past.

My dear child, child of my bosom,

You ask me about life in the past;

I tell you my child, I shall tell you,

Their life, our ancestors of past,

They were of one heart, like mat laid out (for drying paddy),

They never were of different hearts,

My child, this is what I can say,

Our ancestors of old, their lives,

They were then prosperous, it was good,

They were together with one heart.

They were then very prosperous, it was extremely good,

In the beginning of our house in Long Panai, Long Panai.

How hot the day is today,

For us to reminisce, child of my bosom,

Like those in the old, you full moon. 
Ee marung tatah Ubong dih belingah deh menaring - jewey

Ketnun hadui daha na te alem uma dih menuna - jewey

Tiah kenep daha puyo nilung ngakap te ida liling - ateh

Ha nah iha uma maju dih kelalo sayu tih menuna - jewey

Ubong deh belingah usi te sekulah daha menaring - jewey

Piah kenep tua dih te ket daha na dih menuna - jewey

Ee ee nah nunan nah puyo tengaran kui dih uk iduk - edeh

Ee nah avin ika nyihu anih puyo nyihu, nyihu akui - anih

Ha nah iha telo nih ne peji melo ne alem lunang - dan pe'

Ee nah dih nunan tua dih usang tira kui usang jutan - levey

Usi kui kuma haman na puyo tengaran dara

$$
\text { bulan ngembang - levey }
$$

Ee nah li kui lasi nah anih puyo ali usang jutan - lene’

Te dahuk aleng sala puyo dih meng im ala na usang jutan - lene'

Ee em mili puyo awi najuk deh beni' - parei

Ee nah aleng jiek puyo dih im lek tua dih ngen - la'e

Ee nah aleng sayu dih ha dih im tuvu ida keliling - ate'

Ee nunan tua dih nah usang tira kui puyo ali - tete

Ee meng im bero si puyo hado te lusan ka hinan - henei

Ee nah e ika idang kelekkaha bulan ngembang - levey

Ika pejoh en na puyo dih ket im na bulan ngembang - levey

Arap ika lebo tua nih idang menva ka bulan ngembang - levey

Ee nah deh nunan nah tengaran kui dih uk iduk - ede'

Ee kalo lusan ka anih hinam avam dih na-inai

Ee kalo hangu ka anih inu lahu kesaya - teme'

Ee na le kalo nah nih aleng naro' alem lunang - dam pe'

Ee naro' en na nih usang tira kui usang juten - levey

Ee nah ee nunan tua nah usang tira kui bulan ngemban - leveh
Like the story of ubong belingah, in the beginning.

What did they do in the old days?

They were of one heart my child,

That's why, how well and prosperous they were of old.

Ubong...they didn't go to school in the past,

(But), they were always of one heart.

My child, those are my words, just a few,

Because you asked, my child, you asked me,

That's why we are here sitting in lunang.

That's all that I can advise,

I am not good at long words my child,

full moon.

It's me my child,

Don’t take all if I am wrong my child,

Choose wisely my child, like planting seeds,

Leave behind some, my bad advice,

Plant only the good ones in your heart,

This is my advice, child of my bosom.

Don't you forget, there where you are,

If you were like idang kelekkaha, full moon.

Continue my child what you are doing, full moon,

I hope you complete (your journey), full moon.

This is the little of what I can advise,

We, whom you call your mothers,

We, whom you call your relatives,

We are,

This is my advice,

This is my advice, full moon. 
Although the tekná is performed without musical accompaniment, the patterns or motifs of Aren Jok's sadness are conveyed through her extensive vocal range. At times she dexterously used her voice in a soft, low-pitched fashion to express and arouse feelings of sadness and nostalgia to her audience, and at other times the message is accompanied by a strong tonal vocal quality.

\section{Comprehending the tekná: translation, meanings and interpretations}

Translating this tekná proved to be difficult. Even as a native speaker of Kayan, the first author did not understand some of the words and needed the assistance of Margaret Lahung Wan to interpret some unfamiliar old Kayan terms. Similarly, when asked what some of those words mean, the singers themselves were not sure why they used certain words. That is, they use the words intuitively drawing from their memory of having heard the songs performed in the past. Translation difficulties also stem from the fact that some words are poetic, coined or borrowed from archaic constructions, and may function only to fulfil the rhythmic requirements of the line. But further, because the echo words (e.g. - teleh, - jiwey) in each line are perhaps 'sound words' (Rubenstein 1973), they carry no linguistic meaning except that they complement the line final position words. Rubenstein faced similar difficulties when translating other oral traditions of Sarawak. She postulates that some of the words may relate to ancient rituals that are no longer practised:

Even the most knowledgeable informants and interpreters had to admit to gaps in their understanding (of the verses), and had to seek comprehension from longhouse elders, who themselves often needed to confer and search into their collective memory for clues. The singers were often ignorant of the meanings, especially if related ritual was no longer performed. 
(Rubenstein 1989: 85)

Finally, other difficulties derive from the use of metaphor. In the past, the Kayan practice of processing rice was to dry the grains under the sun. The rice seeds were carefully selected and put aside as beni' ${ }^{20}$ (seeds for re-planting). These selected beni' were their most precious possession as they represent life and continuity to the Kayan. The image of the mat upon which they dried their beni' is used metaphorically to draw attention to the attributes of the Kayan who worked together as one people:

Their life, our ancestor of past, they were of one heart, like mat laid out (to dry paddy). They never were of different hearts. My child, this is what I can say, our ancestor of old, they were prosperous. It was good (then).

The Kayan previously lived their communal life solely in the longhouse. Decisions as to where and when to farm were always a collective decision, and meat from hunting was shared among the villagers. As implied, prosperity for the Kayan then was emboldened in their unity, of being 'one heart'. However, this old way of communal living has ceased, and individual decision-making has replaced collective ones in many aspects of Kayan life. Aren Jok’s tekná succinctly articulates this loss of cohesion. Her tekná cleverly conveys the disturbing reminder that the thread that holds the Kayan together is vanishing. As we have noted, Kayan society is rapidly changing. With many people moving out to live in towns, coupled with the incremental shift to modernity in everyday activities in the longhouse itself, and the continuing challenges of transition from old to new; the

\footnotetext{
${ }^{20}$ Apostrophe denotes a glottal stop
} 
old cohesion which was the fabric of society is now under threat more than ever before. Therefore, by using the metaphor of the beni', the singer aptly counsels the listener to choose wisely - as one would choosing the right seeds to plant in the rice field.

Choose wisely my child. Like planting seeds ... plant only the good ones in your heart. Don't forget, there, where you are (living far away in the big city). Continue my child what you are doing ... I hope you complete (your journey).

Bearing these difficulties in mind, it is hoped that with further tekná recorded and transcribed, deeper analyses will be possible.

\section{Conclusion}

We have shown that the tekná is more than just song performance, it is also an expression of what it means to be Kayan. The worldview of the Kayan ancestors is embedded in the narratives of the tekná and references to the values that the Kayan held in the past are as relevant today as they were then. However, in order for tekná to retain its vitality, both the older and the younger generations need to engaged in practising and preserving this tradition for the future. At present only the older generation appears to be aware of the fragility of this important oral tradition. As transmission to the younger generation is crucial, strategies need to be introduced to interest the young in learning and practising the tekná and other oral traditions. For the Kayan to be cognisant of the relevance to their heritage is a stepping stone to increasing interest among the young to want to learn it. 
Cues can be taken from other indigenous language maintenance activities where community-based language projects have used an array of digital platforms and tools in the documentation, preservation and revitalisation of indigenous song and verbal arts (see for instance Treloyn et al. 2013). As noted by Kral and Renganathan (2017) in their research in Australia and Malaysia, finding projects where young people might use modern technology to film or record stories and songs, and then participate in transcription and translation activities, has assisted indigenous youth in seeing the value of their traditions. It is through modern technology that these young people have found a role to play in revitalising the status and value of these old traditions, and enabling them to become the custodians of their traditions into the future.

\section{Acknowledgements}

We wish to thank the Kayan community from the longhouse in Uma Beluvuh, Long Panai, especially the pemanca, Gilbert Ding and his wife Inei Ping Laing and the headman, Gilbert Ding Wan and wife, Aren Anyi. We also wish to thank Aren Jok and her echo singers, and all those who assisted during the field trips. Finally, special thanks to Myfany Turpin for helpful comments on an early draft.

Funding for Roselind Wan and Sumathi Renganathan to visit Sarawak was made available through the Short Term Internal Research Fund (STIRF) of Universiti Teknologi PETRONAS (UTP), undertaken during Wan's PhD study at UTP. Inge Kral is a Co-Investigator on an Australian Research Council - Discovery Indigenous (IN150100018) 'Western Desert Verbal Arts Project'. Initial explorations for this article took place when Roselind Wan was awarded an Endeavour International Fellowship at the School of Literature, Languages and Linguistics, at the Australian National University.

\section{Notes on contributors}

Roselind Wan is a lecturer at the Management and Humanities department, Universiti Teknologi PETRONAS, Malaysia. All the interviews for this fieldwork were conducted in the Kayan language and subsequently translated into English. Email: roselind_wan@utp.edu.my

Sumathi Renganathan is senior lecturer at the Management and Humanities department, Universiti Teknologi PETRONAS, Malaysia.

Email: sumathi@utp.edu.my 
Inge Kral is researcher and lecturer at the Centre for Aboriginal Economic Policy Research and School of Literature, Languages and Linguistics /ARC Centre of Excellence for the Dynamics, Australian National University, Canberra.

Email: inge.kral@anu.edu.au

\section{References}

Anyie, R. L. 1995. The trail of the Kayan Uma Beluvuh. Sarawak Gazette 122 (1532): 16-20.

CBC-Aboriginal. 2010. Legends project: legends of the Kwak’wala. 18 May. <http://www.cbc.ca/aboriginal/2010/05/legends-project-legends-of-the-kwakwala.html> Accessed 4 October 2016.

Cherubini, L. 2008. The metamorphosis of an oral tradition: dissonance in the digital stories of aboriginal peoples in Canada. Oral Tradition 23 (2): 297-314.

Field, M. and Cuero, J. M. 2012. Kumeyaay oral tradition, cultural identity, and language revitalization. Oral Tradition 27 (2): 321-30.

Fox, J.J. 2014. Explorations in semantic parallelism. Canberra: ANU Press. $<$ http://press.anu.edu.au?p=284951>

Hose, C. and McDougall, W. 1912. The pagan tribes of Borneo: a description of their physical, moral and intellectual condition with some discussion on their ethnic relations. London: Macmillan.

Janowski, M. 1991. Rice, work and community among the Kelabit of Sarawak, East Malaysia. PhD thesis, London School of Economics and Political Science.

Jau, C., Teo, M.L. and Yaku, M. 2011. Documenting and perserving tekna’: the Kayans oral tradition. Paper presented at the $3^{\text {rd }}$ International Conference on Applied and Creative Arts (ICACA), UNIMAS, Kuching, Malaysia.

Jensen, M. 2015. The Elders’ documentation project: a Yukon First Nations oral history project. Northern Review 14: 21-7.

Kelbling, S. 1983. Longhouses at the Baluy River. Sarawak Museum Journal 32 (53): 133-58.

Kral, I. and Renganathan, S. 2017. Beyond school: digital cultural practice as a catalyst for language and literacy. In G. Wigglesworth, J. Simpson and J. Vaughan (eds), Language practices of indigenous children and youth: the transition from home to school. London: Palgrave Macmillan, pp. 365-85. 
MacDonald, M. 1956. Borneo people. London: Jonathan Cape.

Marett, A. and Barwick, L. 2003. Endangered songs and endangered languages. In J. Blythe and R.M. Brown (eds), Maintaining the links: language identity and the land. Bath: Foundational for Endangered Languages, pp. 144-51.

Morgan, S. 1980. Looking at literature: interpretation, the Takna' Lawe' and Kayan inequality. Borneo Research Bulletin 12: 47-61.

Nicholas, C. 2004. Stories of a people: asserting place and presence via Orang Asli oral tradition. Paper presented at the seminar on Orang Asli Oral Tradition, Faculty of Social Science and Humanities, Universiti Kebangsaan Malaysia. $<$ https://www.coac.org.my/main.php?section=articles\&article_id=18> Accessed 4 October 2016.

Pakar, G. 2017. A new Kayan journey in old song. New Sarawak Tribune, 7 March. $<$ https://www.newsarawaktribune.com.my/news/a-new-kayan-journey-in-old-song/> Accessed 9 March 2017.

Parks, D.R., Kushner, J., Hooper, W., Flavin, F., Yellow Bird, D. and Ditmar, S. 1999. Documenting and maintaining Native American languages for the 21st century: the Indiana University model. In J. Reyhner, G. Cantoni, R.N. St Clair and E.P. Yazzie, (eds), Revitalizing indigenous languages. Flagstaff AZ: Center for Excellence in Education, Northern Arizona University, pp. 59-83.

Portelli, A. 2003. The order has been carried out. New York: Palgrave.

Rousseau, J. 1975. Ethnic identity and social relations in central Borneo. In J.A. Nagata (ed.), Pluralism in Malaysia: myth and reality. Leiden: E.J. Brill, pp. 32-49

Rousseau, J. 1983. Kayan personal names. Sarawak Museum Journal 32 (53): 251-72.

Rousseau, J. 1990. Central Borneo: ethnic identity and social life in a stratified society. Oxford: Clarendon Press.

Rousseau, J. 1998. Kayan religion: ritual life and religious reform in central Borneo. Leiden: KITLV Press.

Rubenstein, C. 1973. Poems of indigenous peoples of Sarawak: some of the songs and chants. Sarawak Museum Journal Special monograph 2: 289-91.

Rubenstein, C. 1985. The honey tree song: poems and chants of Sarawak Dayaks. Athens OH: Ohio University Press 
Rubenstein, C. 1989. Oral literature research and review: request by Rubenstein for clarification by Maxwell and by Rousseau. Borneo Research Bulletin 21 (2): 83-94.

Rumsey, A. and Niles, D. (eds) 2011. Sung tales from the Papua New Guinea highlands: studies in form, meaning, and sociocultural context. Canberra: ANU Press.

Southwell, C.H. 1980. Kayan - English dictionary. 2nd edn. Kuching: Sarawak Literary Society.

Southwell, C.H. 1999. Unchartered waters: Calgary: Astana Publishing

Thieberger, N. 2013. Curation of oral tradition from legacy recordings: an Australian example. Oral Tradition 28 (2): 253-60.

Treloyn, S., Charles, R.G. and Nulgit, S. 2013. Repatriation of song materials to support intergenerational transmission of knowledge about language in the Kimberley region of northwest Australia. In M.J. Norris, E. Anonby and M-O. Junker (eds), Endangered languages beyond boundaries: proceedings of the 17th FEL conference. Bath: Foundation for Endangered Languages, pp. 18-24.

Turin, M. 2013. Orality and technology, or the bit and the byte: the work of the World Oral Literature Project. Oral Tradition 28 (2): 173-86.

Turpin, M. 2011. Song-poetry of central Australia: sustaining traditions. In J-O. Svantesson, N. Burenhult, A. Holmer, A. Karlsson, and H. Lundstrom (eds), 'Humanities of the lesserknown: an overview’. Language Documentation and Description 10: 15-36. 